\title{
Avocado 'Hass' leaf age affects life table parameters of Oligonychus yothersi (McGregor) (Acari: Tetranychidae) under laboratory conditions
}

\author{
Tommy Rioja ${ }^{1,2}$, Víctor Tello ${ }^{1}$, Miguel Zarzar ${ }^{1}$, Antonieta Cardemil $^{3}$, and Ricardo Ceballos ${ }^{3 *}$ \\ ${ }^{1}$ Universidad Arturo Prat, Facultad de Recursos Naturales Renovables, Campus Huayquique, Casilla 121, Iquique, Chile. \\ ${ }^{2}$ Universidad de Tarapacá, Facultad de Ciencias Agronómicas, Campus Azapa, Casilla 6-D, Arica, Chile. \\ ${ }^{3}$ Instituto de Investigaciones Agropecuarias, INIA Quilamapu, Av. Vicente Méndez 515, Chillán, Chile. \\ "Corresponding author (rceballos@inia.cl).
}

Received: 21 April 2019; Accepted: 8 July 2019; doi:10.4067/S0718-58392019000400557

\begin{abstract}
The avocado red mite Oligonychus yothersi (McGregor) is the most important avocado (Persea americana Mill.) foliar pest in Chile, infesting 'Hass' avocado between mid-summer and late autumn. The post-embryonic development, survival, longevity and life table parameters of $O$. yothersi were evaluated on both young and mature 'Hass' avocado leaves at $25 \pm 0.7{ }^{\circ} \mathrm{C}, 60 \pm 5 \%$ relative humidity and $16: 8 \mathrm{~h}$ photoperiod. The time for larvae, protonymphs and deutonymphs to develop was longer on young leaves than on mature leaves. The immature stage of $O$. yothersi was shorter $(9.29 \pm 0.22$ d) on mature leaves than on young leaves $(14.43 \pm 0.28 \mathrm{~d})$; $O$. yothersi also exhibited higher survival rates for larvae, protonymphs, and deutonymphs on mature leaves. The net reproductive rate $\left(\mathrm{R}_{0}\right) 52.756 \pm 1.749$ individuals female ${ }^{-1}$; intrinsic rate of increase $\left(r_{m}\right) 0.241 \pm 0.002$ female female $^{-1} \mathrm{~d}^{-1}$, and finite rate of increase $(\lambda) 1.273 \pm 0.002$ female female $^{-1}$ of $O$. yothers $i$ were significantly higher on mature avocado leaves than on young leaves $\left(\mathrm{R}_{0}=2.727 \pm 0.271, \mathrm{r}_{\mathrm{m}}=0.049 \pm\right.$ 0.004 , and $\lambda=1.051 \pm 0.004$ ). The time required to double the $O$. yothersi population was only $2.872 \pm 0.002 \mathrm{~d}$ on mature leaves. Therefore, life table parameters of $O$. yothersi are negatively affected by young avocado leaves, suggesting that constitutive defenses present in young leaves could affect $O$. yothersi population parameters.
\end{abstract}

Key word: Avocado red mite, fecundity, life history, post-embryonic, Tetranychidae.

\section{INTRODUCTION}

The avocado red mite Oligonychus yothersi (McGregor) (Acari: Tetranychidae) has been reported in Argentina, Brazil, Chile, Colombia, Costa Rica, Ecuador, Mexico, and USA (California and Florida) (Pinto et al., 2012). It is a key foliar pest in 'Hass' avocado (Persea americana Mill.) orchards in the Valparaíso Region, Chile (Rioja et al., 2015). Oligonychus yothersi feeds on the upper leaf surface, affects leaf physiological parameters, and causes reddish color and discoloration by high oxidative stress, which is a response to $O$. yothersi feeding on the leaf (Hoy, 2011; Rioja et al., 2016). High $O$. yothersi infestations are also reported between mid-summer and late autumn, whereas the $O$. yothersi population is not observed during rainy seasons with low temperatures and short days (winter and early spring), indicating that those abiotic factors could affect the population outbreaks at the Quillota location (Ripa and Larral, 2008).

Several studies indicate that abiotic factors such as temperature (Bayu et al., 2017), relative humidity (RH) (Yang et al., 2015), and photoperiod (Shah et al., 2011), affect phytophagous mite population parameters; different genotypes and cultivars influence mite development and fecundity (Sedaratian et al., 2011; Modarres, 2012). On the other hand, the life 
table is a useful method in integrated pest management programs (Jaleel et al., 2018), evaluations of potential predators (Puchalska and Kozak, 2016), tolerance and/or resistance of host plants (Khanamani et al., 2014), rearing improvement (Al-Shemmary, 2018), and predictions of population outbreaks under field conditions (Kane et al., 2017).

Another factor that could affect the life table parameters of tetranychid mites is leaf age, which has been inadequately studied. However, there are reports of $O$. punicae (Hirst) and Tetranychus urticae (Koch) in which post-embryonic development and oviposition were negatively affected when they were reared on young leaves with high constitutive defenses (McMurtry, 1970; Larson and Berry, 1984; Kielkiewicz and van de Vrie, 1990). Field observations show that the avocado red mite mainly infests mature leaves from spring vegetative flush in mid-summer, suggesting that leaf age influences $O$. yothersi reproductive parameters.

There are some life table studies of tetranychid mites belonging to the Oligonychus gender, specifically $O$. gossypii (Zacher) (Bonato et al., 1995), O. perseae Tuttle, Baker and Abatiello (Kerguelen and Hoddle, 2000), O. afrasiaticus (McGregor) (Chaaban et al., 2011), O. mangiferus (Rhaman and Sapra) (Lin, 2013), O. punicae (Hirst) (Vásquez et al., 2008; Cerna et al., 2009), and $O$. litchi Lo and Ho (Chen et al., 2016). There are also biological studies of $O$. coffeae Nietner, and O. cubensis Livschitz (Roy et al., 2014; Chavez-Espinoza et al., 2017), but no studies about life table parameters of $O$. yothersi (Rioja and Vargas, 2009). Considering all the above, we hypothesized that life table parameters of $O$. yothers $i$ will be negatively affected by young leaves of avocado. Therefore, in the present study, we evaluated the influence of avocado leaf age on the life table parameters of $O$. yothersi under controlled laboratory conditions using leaves of different ages. The obtained information will help to improve laboratory rearing systems by using suitable leaves and implement integrated mite management programs.

\section{MATERIALS AND METHODS}

\section{Mite colony}

Oligonychus yothersi (McGregor) was collected from 'Hass' avocado orchards at La Cruz (3249' S; 71¹7' W), Valparaíso Region, Chile. The material was transported to a laboratory for taxonomic identification. The identified material was then used to rear avocado red mites under laboratory conditions, on avocado leaf discs ( $6 \mathrm{~cm}$ diameter) according to the methodology described by Rioja et al. (2015). Recorded laboratory conditions were $23 \pm 3^{\circ} \mathrm{C}, 60 \pm 10 \% \mathrm{RH}$ and $16: 8 \mathrm{~h}$ photoperiod.

\section{Avocado leaves}

To determine the influence of leaf age on the life table parameters of $O$.yothersi, mature 'Hass' avocado shoots (7-mo-old) were collected from spring vegetative flush at La Cruz location. These shoots were cleaned with distilled water and their leaves used as discs for the experiments. The same procedure was performed for young 'Hass' avocado shoots (2-moold) from summer vegetative flush. All the avocado shoots were from an avocado orchard and collected during February and March 2014. A completely expanded and thin leaf with light green coloring was considered as a young leaf, while a completely developed and thick leaf with dark green coloring was considered as a mature leaf (Walker and Zareh, 1990).

\section{Post-embryonic development, longevity and survival of Oligonychus yothersi}

Five $O$. yothersi gravid females were placed in a Petri dish $(8 \mathrm{~cm}$ diameter, $1.5 \mathrm{~cm}$ height $)$ containing a mature avocado leaf disc ( $6 \mathrm{~cm}$ diameter) on wet cotton. To provide moisture for the wet cotton, a hole was made in the bottom of each Petri dish, and all Petri dishes were placed on wet sponges in plastic containers $(29 \times 7 \times 39.5 \mathrm{~cm})$ (Rioja et al., 2015). This procedure was repeated for 30 Petri dishes and all females were removed from the Petri dishes after $4 \mathrm{~h}$, leaving one egg per leaf disc ( $1 \mathrm{egg}=1$ replicate). Thirty replicates were performed, and egg-adult development and longevity were recorded every $24 \mathrm{~h}$ until the death of the adults. The exuviae were used to differentiate each developmental stage and all exuviae were discarded. For each replicate, the growing mite was carefully transferred with a fine brush to a new leaf disc every $6 \mathrm{~d}$. The egg laid by each unmated female was eliminated. All observations were performed with a 40X stereoscopic magnifying glass (Zeiss, Stemi, Göttingen, Germany). The gravid females used in this study were maintained on mature avocado leaf discs for $72 \mathrm{~h}$ to ensure the influence of leaf feeding. The plastic containers were placed inside an incubator (Thermo Scientific Precision Model 818 Incubator, Marietta, Ohio, USA) at $25 \pm 0.7{ }^{\circ} \mathrm{C}, 60 \pm 5 \% \mathrm{HR}$, and $16: 8 \mathrm{~h}$ 
photoperiod. The same procedure was used for young avocado leaf discs to record the effect of leaf age on postembryonic development, longevity and survival.

\section{Life table parameters}

The female cohort was studied. A newly emerged female was carefully transferred to an avocado leaf disc with three young males, and when the males died, they were replaced by others. The eggs laid on each leaf disc were counted and eliminated every $24 \mathrm{~h}$ until the female died; 30 replicates $(1$ female $=1$ replicate) were performed to record life table parameters. To calculate the sex ratio (female percentage of the studied female cohort) and number of $O$. yothersi female offspring, 10 replicates were randomly selected and observed every $24 \mathrm{~h}$. Sex ratios for the offspring of the females were determined by body size and opisthosoma shape $(O$. yothersi females are larger and have a rounded opisthosoma, while males are smaller and have a sharper opisthosoma) with a 40X stereoscopic magnifying glass (Zeiss, Stemi, Göttingen, Germany). Leaf discs were kept at $25 \pm 0.7^{\circ} \mathrm{C}, 60 \pm 5 \% \mathrm{HR}$, and $16: 8 \mathrm{~h}$ photoperiod. The same procedure was used for both young and mature leaf discs.

\section{Statistical analysis}

Previously, data were examined to verify normality using Kolmogorov-Smirnov test. Then, post-embryonic development and longevity data were normalized using $\ln (\mathrm{x}+1)$, while survival data were transformed using arcsine $\sqrt{ } \mathrm{x}$ prior to the ANOVA. The $t$-test $(\mathrm{P}<0.05)$ was used to compare young and mature leaves. The same procedure was used to analyze the pre-oviposition, oviposition, and post-oviposition periods.

To construct the $O$. yothersi female age-specific life table, the female cohort under study in the experiments was considered. The following life table parameters were calculated: net reproductive rate $\left(R_{0}=\Sigma l_{x} m_{x}\right.$, number of females produced per female during its lifetime), intrinsic rate of increase $\left(\mathrm{r}_{\mathrm{m}}\right)$ was estimated from $\sum e^{-r(x+1)}\left(l_{x} m_{x}\right)=1$ (where $x$ is the female age in days, $l_{x}$ is the survival rate of females at age $x, m_{x}$ is the mean number of females offspring produced per female at age $x$, and $l_{x} m_{x}$ is the net number of females offspring produced per female), finite rate of increase $\left(\lambda=e^{r m}\right)$, number of females offspring produced by a female per day, mean generation time $\left(T=\left(\ln R_{0}\right) / r_{m}\right)$, and doubling time $(D T$ $\left.=(\ln 2) / r_{m}\right)($ Birch, 1948). To determine statistical differences in the life table parameters, the jackknife non-parametric method was applied (Meyer et al., 1986), pseudo-values were obtained for each parameter, and the mean, variance, and standard error were estimated; those parameters were then compared by the $t$-test $(\mathrm{P}<0.05)$. To calculate life table parameters and their pseudo-values, the lifetable.r program was used ( $\mathrm{R}$ version 3.4.4) which was developed by Maia et al. (2014) with Software R, a language and environment for statistical computing (Dalgaard, 2010).

\section{RESULTS AND DISCUSSION}

\section{Development and longevity of Oligonychus yothersi on avocado leaves}

The development period of $O$. yothersi was significantly shorter in the immature stages (eggs: $\mathrm{t}=6.22, \mathrm{df}=58, \mathrm{P}=$ 0.0001 , larvae: $\mathrm{t}=5.63, \mathrm{df}=42, \mathrm{P}=0.0001$, protonymphs; $\mathrm{t}=4.72, \mathrm{df}=35, \mathrm{P}=0.0001$, and deutonymph: $\mathrm{t}=6.98, \mathrm{df}=$ $33, \mathrm{P}=0.0001$ ) on mature leaves compared with young leaves (Table 1). In addition, survival of mites reaching adulthood was significantly higher on mature leaves $(\mathrm{t}=-7.68, \mathrm{df}=33, \mathrm{P}=0.0001)$. There were nonsignificant differences in the longevity of unmated adults $(\mathrm{t}=0.17, \mathrm{df}=33, \mathrm{P}=0.8689)$ on both young and mature leaves, although mated adults lived longer on mature leaves $(\mathrm{t}=-5.48, \mathrm{df}=58, \mathrm{P}=0.0001)$. The sex ratio was $61.5 \%$ females and $38.5 \%$ males on mature leaves; however, the sex ratio was $47.4 \%$ females and $52.6 \%$ males on young leaves.

Our results show that young avocado leaves negatively affected the development and survival of $O$. yothersi; the postembryonic development of $O$. yothersi was longer (14.43 d), and had higher mortality rates at all stages on young avocado leaves compared with mature leaves (9.29 d). Likewise, Larson and Berry (1984) found that the development of immature T. urticae was longer on young peppermint (Mentha piperita L.) leaves, which contained high quantities of phenolics compounds and total monoterpenes when compared with mature leaves. Kielkiewicz and van de Vrie (1990) analyzed the content of phenolic substances, total $\mathrm{N}$, and soluble protein in chrysanthemum (Dendranthema grandiflora Tzvelev) leaves. They showed lower T. urticae densities on young chrysanthemum leaves with high quantities of N, phenols, and polyphenol compounds, which suggests that the main factor that would affect the biological parameters 
Table 1. Post-embryonic development, longevity and survival of Oligonychus yothersi (mean $\pm \mathrm{SE}$ ) on 'Hass' avocado leaves at $25 \pm 0.7^{\circ} \mathrm{C}$ and $60 \pm 0.5 \% \mathrm{RH}$.

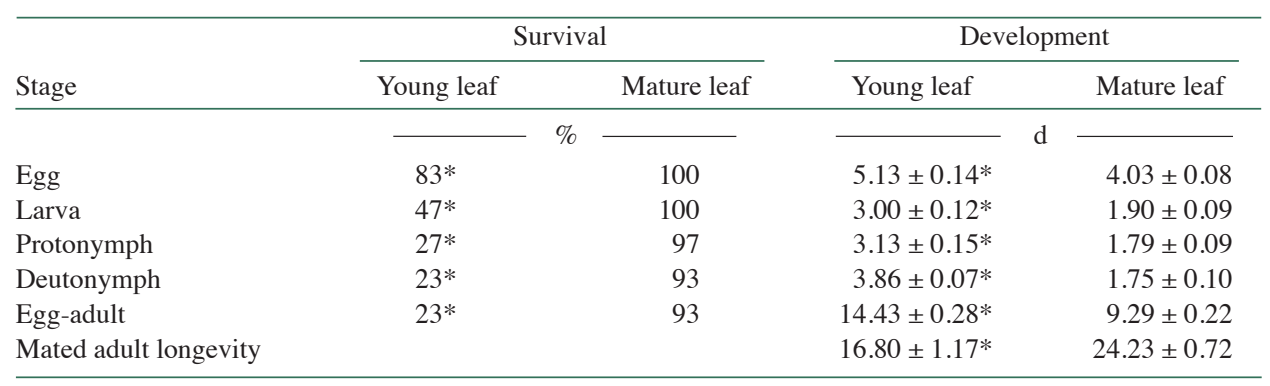

*Significant differences between young and mature leaf, for each stage and parameter, according Student's t-test $(\mathrm{P}<0.05)$.

of $T$. urticae are the constitutive defenses more than the leaf nutritional levels. Some studies indicate that young shoots and expanding leaves require and exhibit high $\mathrm{N}$ content in their development as well as high levels of constitutive defenses and anti-feeding compounds to prevent herbivory (Bixenmann et al., 2013; Silva et al., 2015; Wiggins et al., 2016). Although these compounds were not measured in the present study, the only factor that could have affected the development and survival of $O$. yothersi was the chemical leaf composition associated with age, because the experiments were carried out on leaves of the same plant cultivar and under controlled conditions. Therefore, further studies about the chemical composition of avocado leaves in different phenological stages are necessary.

Furthermore, the development time from egg-to-adult of $O$. yothersi was shorter $(9.29 \mathrm{~d})$ on mature 'Hass' avocado leaves at $25^{\circ} \mathrm{C}$ compared to young leaves, Chavez-Espinoza et al. (2017) studied the biology of $O$. cubensis on mature 'Criollo' avocado leaves at $22.83 \pm 1.31^{\circ} \mathrm{C}$, who recorded a development time from egg-to-adult of $10.91 \mathrm{~d}$. Cerna et al. (2009) found that the duration from egg-to-adult of $O$. punicae on 'Hass' and 'Criollo' avocado leaves at $24 \pm 2{ }^{\circ} \mathrm{C}$ were 7.78 and $9.54 \mathrm{~d}$, respectively. The slight differences shown in mite development belonging to the Oligonychus gender were mainly influenced by avocado cultivar and ambient conditions because mature avocado leaves were used in the previously mentioned studies.

We observed that the fecundity of $O$. yothersi was higher on mature avocado leaves than on young leaves. McMurtry (1970) found that the oviposition rate (eggs female ${ }^{-1} \mathrm{~d}^{-1}$ ) of $O$. punicae was higher on mature Persea indica leaves than on young leaves. Likewise, Larson and Berry (1984) recorded lower oviposition (eggs leaf ${ }^{-1}$ ) of T. urticae on young peppermint leaves, which exhibited high phenolic content compared with mature leaves, suggesting that the constitutive compounds of young leaves affected mite's fecundity.

\section{Life table parameters of Oligonychus yothersi on avocado leaves}

There were significant differences in the pre-oviposition period, which was shorter on mature leaves $(\mathrm{t}=15.32, \mathrm{df}=58$, $\mathrm{P}=0.0001)$; furthermore, the oviposition period was significantly longer $(\mathrm{t}=-7.25, \mathrm{df}=58, \mathrm{P}=0.0001)$, and with higher fecundity $(\mathrm{t}=-15.07, \mathrm{df}=58, \mathrm{P}=0.0001)$ on mature leaves than on young leaves (Table 2$)$.

The female survival rate $\left(l_{x}\right)$ on young leaves decreased to $23 \%$ by day 10 , remained over $20 \%$ for $10 \mathrm{~d}$, and then decreased. A higher survival rate was recorded for females on mature leaves, with a mean of $88 \%$ up to day 25 , and then gradually decreased (Figure 1). The net reproductive rate $\left(\mathrm{R}_{0}\right)$, intrinsic rate of increase $\left(\mathrm{r}_{\mathrm{m}}\right)$ and finite rate of increase $(\lambda)$ parameters were significantly higher $(\mathrm{t}=28.26, \mathrm{df}=58, \mathrm{P}=0.0001, \mathrm{t}=45.07, \mathrm{df}=58, \mathrm{P}=0.0001$, and $\mathrm{t}=47.88, \mathrm{df}=58$,

Table 2. Reproductive periods of Oligonychus yothersi (mean \pm SE) on 'Hass' avocado leaves at $25 \pm 0.7^{\circ} \mathrm{C}$ and $60 \pm 0.5 \% \mathrm{RH}$.

\begin{tabular}{lrr}
\hline Stage & \multicolumn{1}{c}{ Young leaf } & Mature leaf \\
\hline Pre-oviposition period & $2.40 \pm 0.09^{*}$ & $1.07 \pm 0.05$ \\
Oviposition period & $13.63 \pm 0.93^{*}$ & $22.20 \pm 0.67$ \\
Post-oviposition period & $3.17 \pm 0.65^{*}$ & $2.00 \pm 0.30$ \\
Fecundity (eggs per female) & $20.80 \pm 2.07^{*}$ & $79.93 \pm 2.65$ \\
\hline
\end{tabular}

*Significant differences between young and mature leaf, for each stage, according Student's t-test $(\mathrm{P}<0.05)$. 
Figure 1. Age-specific survival rate $\left(\mathrm{I}_{\mathrm{x}}\right)$ and age-specific fecundity rate $\left(\mathrm{m}_{\mathrm{x}}\right)$ of Oligonychus yothersi females on young (A) and mature (B) 'Hass' avocado leaves at $25 \pm 0.7^{\circ} \mathrm{C}$ and $60 \pm 5 \% \mathrm{RH}$.

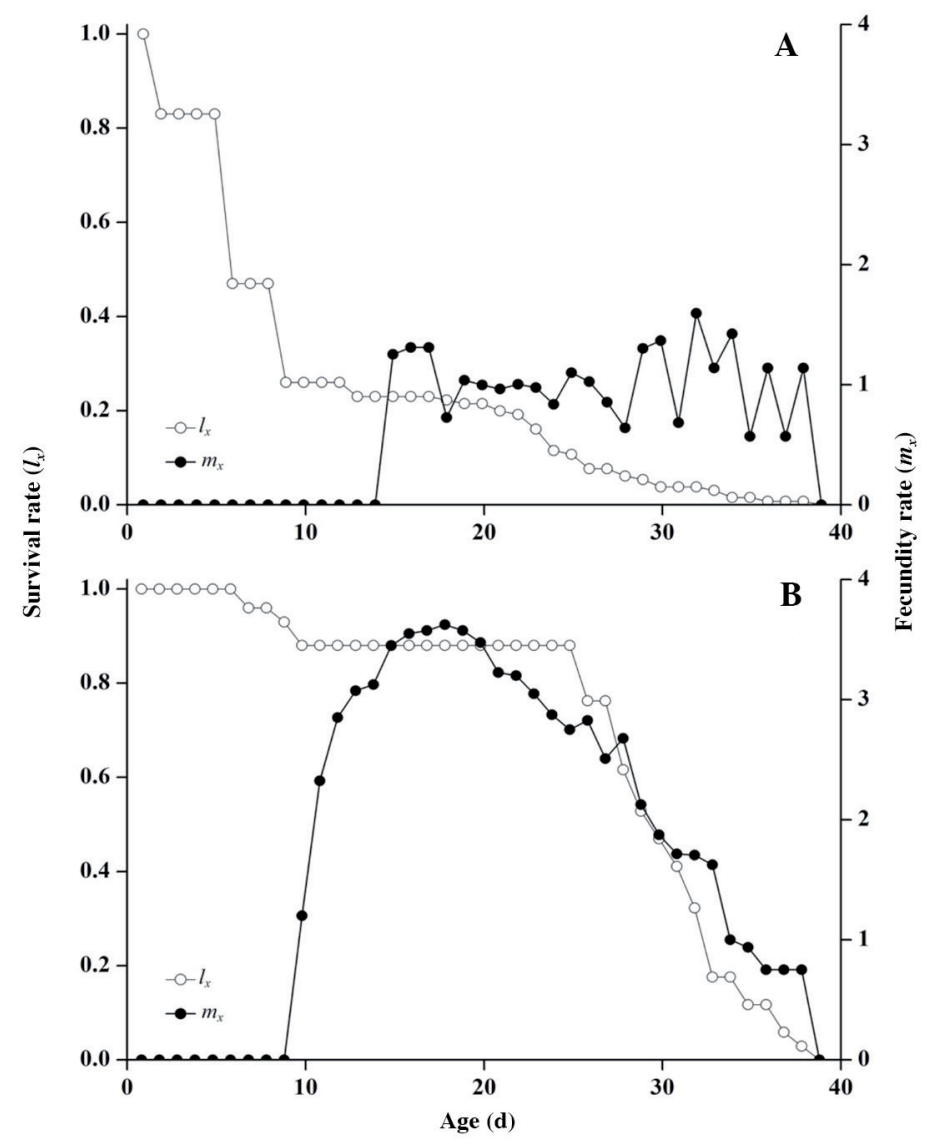

$\mathrm{P}=0.0001$, respectively) on mature leaves; in addition, there were significant differences in both mean generation time (T) and doubling time parameters $(\mathrm{DT})(\mathrm{t}=-6.55, \mathrm{df}=58, \mathrm{P}=0.0001$, and $\mathrm{t}=-9.82, \mathrm{df}=58, \mathrm{P}=0.0001$, respectively $)$ with longer times recorded on young leaves (Table 3 ).

The $\mathrm{R}_{0}, \mathrm{r}_{\mathrm{m}}$, and $\lambda$ parameters of $O$. yothersi were higher on mature avocado leaves than on young leaves. Kerguelen and Hoddle (2000) evaluated the biological parameters of $O$. perseae on 'Hass' avocado leaves collected in late spring, early summer, and mid-summer; they found that $\mathrm{R}_{0}$ and $\mathrm{r}_{\mathrm{m}}$ were significantly higher in mid-summer and suggested that the main factor was the nutritional quality of the leaves in that period. Rioja and Vargas (2009) recorded the population growth parameters of $O$. yothersi on mature 'Hass' avocado leaves (10-mo-old), and found that values for $\mathrm{R}_{0}(39.66), \mathrm{r}_{\mathrm{m}}$ $(0.22)$, and $\lambda(1.25)$. These values were lower than those found in the present study $\left(\mathrm{R}_{0}=52.75, \mathrm{r}_{\mathrm{m}}=0.24\right.$, and $\left.\lambda=1.27\right)$ in which 7-mo-old leaves from spring vegetative flush were used. Salazar-García and González-Durán (2015) recorded that avocado leaves from winter vegetative flush lived for $12.5 \mathrm{mo}$, while leaves from summer vegetative flush lived for 7.8 mo; this suggests that winter-spring leaves with long lifespan are the most suitable to increase population. Motahari et al.

Table 3. Life-table parameters of Oligonychus yothersi (mean \pm SE) on 'Hass' avocado leaves at $25 \pm 0.7^{\circ} \mathrm{C}$ and $60 \pm 0.5 \% \mathrm{RH}$.

\begin{tabular}{lrr}
\hline Parameters & \multicolumn{1}{c}{ Young leaf } & \multicolumn{1}{c}{ Mature leaf } \\
\hline Net reproductive rate $\left(\mathrm{R}_{0}\right)$ & $2.727 \pm 0.271^{*}$ & $52.756 \pm 1.749$ \\
Intrinsic rate of increase $\left(\mathrm{r}_{\mathrm{m}}\right)$ & $0.049 \pm 0.004^{*}$ & $0.241 \pm 0.002$ \\
Finite rate of increase $(\lambda)$ & $1.051 \pm 0.004^{*}$ & $1.273 \pm 0.002$ \\
Mean generation time $(\mathrm{T})$ & $20.318 \pm 0.571^{*}$ & $16.436 \pm 0.156$ \\
Doubling time (DT) & $13.858 \pm 1.119^{*}$ & $2.872 \pm 0.002$ \\
\hline
\end{tabular}

*Significant differences between young and mature leaf, for each stage, according Student's t-test $(\mathrm{P}<0.05)$. 
(2014) evaluated four N levels on the life table parameters of T. urticae in cucumber (Cucumis sativus L. 'Sultan') plants; they did not demonstrate significant differences between the excess and deficient $\mathrm{N}$ treatments, indicating that $\mathrm{N}$ content in the cucumber plant did not affect the biological parameters of T. urticae. In addition, Salazar-García and GonzálezDurán (2015) found that the higher N concentrations occurred in mid-summer and recorded a maximum of 21.4 and 24.9 $\mathrm{g} \mathrm{kg}^{-1}$, in leaves from winter and summer vegetative flushes, respectively. It seems that avocado leaf $\mathrm{N}$ content would not have a greater effect on the life table parameters of $O$. yothersi on young leaves, each $O$. yothersi female produce 2.727 females offspring $\left(\mathrm{R}_{0}\right), 0.049$ females female ${ }^{-1} \mathrm{~d}^{-1}\left(\mathrm{r}_{\mathrm{m}}\right)$, and delay $13.858 \mathrm{~d}$ to double its population on leaves with high N content during mid-summer (Salazar-García and González-Durán, 2015). On the other hand, on mature leaves with lower N content, each $O$. yothersi female can produce 52.756 females offspring and doubles the population in only 2.872 $\mathrm{d}$, which agrees with the high $O$. yothersi population peaks observed infesting spring-shoots in 'Hass' avocado orchards during mid-summer and late autumn at the Quillota location. Therefore, $\mathrm{N}$ is not a relevant factor in this case, because there are slight differences in $\mathrm{N}$ content in summer and winter-spring avocado leaves, as previously mentioned (SalazarGarcía and González-Durán, 2015). The life table parameters of $O$. yothersi are affected by leaf age, constitutive defenses seem to be the main factor negatively affecting the biological parameters of $O$. yothersi. Further studies are necessary to identify the secondary compounds present in avocado leaves from spring and summer vegetative flushes.

\section{CONCLUSIONS}

The physiological age of avocado leaves influenced the development time, fecundity, and survival of avocado red mite Oligonychus yothersi. In controlled conditions, the life table parameters net reproductive rate, intrinsic rate of increase and finite rate of increase of $O$. yothersi are lower on 2-mo-old leaves than 7-mo-old.

\section{ACKNOWLEDGEMENTS}

We thank the staff, equipment and facilities of the Instituto de Investigaciones Agropecuarias INIA, Centro Regional de Investigación La Cruz, Valparaíso Region of Chile.

\section{REFERENCES}

Al-Shemmary, K.A. 2018. The availability of rearing Neoseiulus cucumeris (Oud.) and Neoseiulus barkeri (Hughes) (Acari: Phytoseiidae) on three insect egg species. Egyptian Journal of Biological Pest Control 28:79. doi:10.1186/s41938-018-0084-6.

Bayu, M.S.Y.I., Ullah, M.S., Takano, Y., and Gotoh, T. 2017. Impacts of constant versus fluctuating temperatures on the development and life history parameters of Tetranychus urticae (Acari: Tetranychidae). Experimental and Applied Acarology 72:205-227. doi:10.1007/s10493-017-0151-9.

Birch, L.C. 1948. The intrinsic rate of increase and insect population. Journal of Animal Ecology 17:15-26. doi:10.2307/1605.

Bixenmann, R.J., Coley, P.D., and Kursar, T.A. 2013. Developmental changes in direct and indirect defenses in the young leaves of the neotropical tree genus Inga (Fabaceae). Biotropica 45:175-184. doi:10.1111/j.1744-7429.2012.00914.x.

Bonato, O., Mapangou-Divassa, S., and Gutierrez, J. 1995. Influence of relative humidity on life-history parameters of Mononychellus progresivus and Oligonychus gossypii (Acari: Tetranychidae). Environmental Entomology 24:841-845. doi:10.1093/ee/24.4.841.

Cerna, E., Badii, M.H., Ochoa, Y., Aguirre, L.A., and Landeros, J. 2009. Life table of Oligonychus punicae Hirst (Acari: Tetranychidae) in avocado leaves (Persea americana Mill) in the hass, fuerte and criollo cultivars. Universidad y Ciencia 25:133-140.

Chaaban, S.B., Chermiti, B., and Kreiter, S. 2011. Comparative demography of the spider mite, Oligonychus afrasiaticus, on four date palm varieties in southwestern Tunisia. Journal of Insect Science 11:136. doi:10.1673/031.011.13601.

Chavez-Espinoza, A., Rodríguez, H., and Estrada-Venegas, E.G. 2017. Biology of Oligonychus cubensis Livschitz (Acari: Tetranychidae) in avocado (Persea americana Miller). Revista de Protección Vegetal 32:1-7.

Chen, W-H., Li, C-Y., and Chang, T-Y. 2016. Temperature-dependent development and life history of Oligonychus litchi (Acari: Tetranychidae), on wax apple. Journal of Asia-Pacific Entomology 19:173-179. doi:10.1016/j.aspen.2016.01.004.

Dalgaard, P. 2010. R Development Core Team (2010): R: A language and environment for statistical computing. Computer program. Available at http://www.R-project.org (accessed 22 June 2018).

Hoy, M.A. 2011. Agricultural Acarology: introduction to integrated pest management. CRC Press, Boca Raton, Florida, USA. 
Jaleel, W., Lu, W., and He, Y. 2018. Biology, taxonomy, and IPM strategies of Bactrocera tau Walker and complex species (Diptera: Tephritidae) in Asia: a comprehensive review. Environmental Science and Pollution Research 25:19346-19361. doi:10.1007/s11356-018-2306-6.

Kane, K., Sedinger, J.S., Gibson, D., Blomberg, E., and Atamian, M. 2017. Fitness landscapes and life-table response experiments predict the importance of local areas to population dynamics. Ecosphere 8:e01869. doi:10.1002/ecs2.1869.

Kerguelen, V., and Hoddle, M.S. 2000. Comparison of the susceptibility of several cultivars of avocado to the persea mite, Oligonychus perseae (Acari: Tetranychidae). Scientia Horticulturae 84:101-114. doi:10.1016/S0304-4238(99)00103-X.

Khanamani, M., Fathipour, Y., Hajiqanbar, H., and Sedaratian, A. 2014. Two-spotted spider mite reared on resistant eggplant affects consumption rate and life table parameters of its predator, Thyphlodromus bagdasarjani (Acari: Phytoseiidae). Experimental and Applied Acarology 63:241-252. doi:10.1007/s10493-014-9785-z.

Kielkiewicz, M., and van de Vrie, M. 1990. Within-leaf differences in nutritive value and defence mechanism in chrysanthemum to the two-spotted spider mite (Tetranychus urticae). Experimental and Applied Acarology 10:33-43. doi:10.1007/BF01193971.

Larson, K.C., and Berry, R.E. 1984. Influence of peppermint phenolics and monoterpenes on two spotted spider mite (Acari: Tetranychidae). Environmental Entomology 13:282-285. doi:10.1093/ee/13.1.282.

Lin, M-Y. 2013. Temperature-dependent life history of Oligonychus mangiferus (Acari: Tetranychidae) on Mangifera indica. Experimental and Applied Acarology 61:403-413. doi:10.1007/s10493-013-9716-4.

Maia, A.H., Pazianotto, R.A., Luiz, A.J., Marhino-Prado, J.S., and Pervez, A. 2014. Inference on arthropod demographic parameters: computational advances using R. Journal of Economic Entomology 107:432-439. doi:10.1603/EC13222.

McMurtry, J.A. 1970. Some factors of foliage condition limiting population growth of Oligonychus punicae (Acari: Tetranychidae). Annals of the Entomological Society of America 63:406-412. doi:10.1093/aesa/63.2.406.

Meyer, J.S., Ingersoll, C.G., McDonald, L.L., and Boyce, M.S. 1986. Estimating uncertainty in population growth rates: Jackknife vs. Bootstrap techniques. Ecology 67:1156-1166. doi:10.2307/1938671.

Modarres, S.S. 2012. Comparative biology and fertility life tables of Tetranychus urticae Koch (Acari: Tetranychidae) on different common bean cultivars. International Journal of Acarology 38:706-714. doi:10.1080/01647954.2012.714402.

Motahari, M., Kheradmand, K., Roustaee, A.M., and Talebi,A.A. 2014. The impact of cucumber nitrogen nutrition on life history traits of Tetranychus urticae (Koch) (Acari: Tetranychidae). Acarologia 54:443-452. doi:10.1051/acarologia/20142137.

Pinto, R., Ferreira, J.A.M., Pires, E.M., and Zanuncio, J.C. 2012. New record and characteristic of damage caused by Oligonychus yothersi on Eucaliptus urophylla. Phytoparasitica 40:143-145. doi:10.1007/s12600-011-0217-x.

Puchalska, E.K., and Kozak, M. 2016. Typhlodromus pyri and Euseius finlandicus (Acari: Phytoseiidae) as potential biocontrol agents against spider mites (Acari: Tetranychidae) inhabiting willows: laboratory studies on predator development and reproduction on four diets. Experimental and Applied Acarology 68:39-53. doi:10.1007/s10493-015-9973-5.

Rioja, T., Ceballos, R., Holuigue, L., and Vargas, R. 2016. Different population densities and continuous feeding by Oligonychus yothersi (McGregor) (Acari: Tetranychidae) affect the emissions of herbivore-induced plant volatiles on avocado (Persea americana Mill. cv. Hass) shoots under semi-field conditions. International Journal of Acarology 42:310-318. doi:10.1080/01647954.2016.1191539.

Rioja, T., Ceballos, R., Rebolledo, R., and Vargas, R. 2015. Rearing and development of Oligota pygmaea and Parastethorus histrio (Coleoptera: Staphylinidae, Coccinellidae) feeding on Oligonychus yothersi (Acari: Tetranychidae) and survival on non-mite foods under laboratory conditions. International Journal of Acarology 41:681-687. doi:10.1080/01647954.2015.1094513.

Rioja, T., and Vargas, R. 2009. Life table parameters and consumption rate of Cydnodromus picanus Ragusa, Amblyseius graminis Chant, and Galendromus occidentalis (Nesbitt) on avocado red mite Oligonychus yothersi (McGregor) (Acari: Phytoseiidae, Tetranychidae). Chilean Journal of Agricultural Research 62:160-170. doi:10.4067/S0718-58392009000200005.

Ripa, R., y Larral, P. 2008. Manejo de plagas en paltos y cítricos. Colección Libros INIA N²3. 399 p. Instituto de Investigaciones Agropecuarias, INIA La Cruz, Quillota, Chile.

Roy, S., Muraleedharan, N., and Mukhopadhyay, A. 2014. The red spider mite, Oligonychus coffeae (Acari: Tetranychidae): its status, biology, ecology and management in tea plantations. Experimental and Applied Acarology 63:431-463. doi:10.1007/s10493-014-9800-4.

Salazar-García, S., and González-Durán, I.J.L. 2015. Identification of the appropriate leaf sampling period for nutrient analysis in 'Hass' avocado. HortScience 50:130-136.

Sedaratian, A., Fathipour, Y., and Moharramipour, S. 2011. Comparative life table analysis of Tetranychus urticae (Acari: Tetranychidae) on 14 soybean genotypes. Insect Science 18:541-553. doi:10.1111/j.1744-7917.2010.01379.x.

Shah, M., Suzuki, T., Ghazy, N.A., Amano, H., and Ohyama, K. 2011. Effect of photoperiod on immature development and diapauses induction in the Kanzawa spider mite, Tetranychus kanzawai (Acari: Tetranychidae). Experimental and Applied Acarology 55:183-190. doi:10.1007/s10493-011-9462-4.

Silva, J.O., Espírito-Santo, M.M., and Morais, H.C. 2015. Leaf traits and herbivory on deciduous and evergreen trees in a tropical dry forest. Basic and Applied Ecology 16:210-219. doi:10.1016/j.baae.2015.02.005. 
Vásquez, C., Aponte, O., Morales, J., Sanabria, M.E., and García, G. 2008. Biological studies of Oligonychus punicae (Acari: Tetranychidae) on grapevine cultivars. Experimental and Applied Acarology 45:59-69. doi:10.1007/s10493-008-9154-x.

Walker, G.P., and Zareh, N. 1990. Leaf age preference for oviposition by three species of whitefly on lemon. Entomologia Experimentalis et Applicata 56:31-45. doi:10.1111/j.1570-7458.1990.tb01379.x.

Wiggins, N.L., Forrister, D.L., Endara, M-J., Coley, P.D., and Kursar, T.A. 2016. Quantitative and qualitative shifts in defensive metabolites define chemical defense investment during leaf development in Inga, a genus of tropical trees. Ecology and Evolution 6:478-492. doi:10.1002/ece3.1896.

Yang, Y., Li, W., Xie, W., Wu, Q., Xu, B., Wang, S., et al. 2015. Development of Bradysia odoriphaga (Diptera: Sciaridae) as affected by humidity: and age - stage, two sex, life-table study. Applied Entomology and Zoology 50:310. doi:10.1007/s13355-014-0295-6. 